\title{
Geological probability calculation of new gas discoveries in wider area of Ivana and Ika Gas Fields, Northern Adriatic, Croatia
}

\author{
Ocena geološke verjetnosti novih odkritij naravnega plina na širšem \\ območju plinskih polj Ivana in Ika v hrvaškem delu severnega \\ Jadrana
}

\author{
Malvić Tomislav' ${ }^{1}$ Velić Josipa', Mate Režić2* \\ ${ }^{1}$ University of Zagreb, Faculty of Mining, Geology and Petroleum Engineering, Pierottijeva 6, 10000 Zagreb, Croatia \\ ${ }^{2}$ Stepinčeva 16, 21000 Split, Croatia \\ *mate.rezic92@hotmail.com
}

\begin{abstract}
There are eleven reservoirs in Ivana Gas Field and they are composed of Pleistocene sands, silt sands and siltstones, developed in dominant clays and marls depositional sequences. Ika Gas Field is the only field in Adriatic with gas accumulated in carbonate rocks, which are the deepest reservoir of the total four reservoirs. A carbonate reservoir is defined with tectonical and erosional unconformity, which is placed between Mesozoic and Pliocene rocks. The three younger Ika reservoirs are composed of Pleistocene sands, silt sands and siltstones that are laminated into clays and marls. The goal of our study was to assess the 'Probability of Success' (POS) of finding new gas accumulations within the marginal area of those two fields, either in the form of Mesozoic rocks or Pleistocene deposits. The assessment was successfully completed using the Microsoft Excel POS table for the analyzed areas in the Croatian part of the Po Depression, namely, Northern Adriatic. The methodology was derived and adapted from a similar POS calculation, which was originally used to calculate the geological probability of hydrocarbon discoveries in the Croatian part of the Pannonian Basin System (CPBS).
\end{abstract}

Key words: northern Adriatic, probability of success, Mesozoic, Pleistocene, geological modelling

\section{Izvleček}

$\mathrm{V}$ plinskem polju Ivana je enajst plinonosnih rezervoarjev, ki sestoje iz pleistocenskih peskov, meljastih peskov in meljev, odloženih v prevladujoče glinenih in lapornih sedimentacijskih zaporedjih. Plinsko polje Ika je edino $\mathrm{v}$ Jadranskem morju, $\mathrm{v}$ katerem je plin $\mathrm{v}$ karbonatnih kamninah, in katerega rezervoar je najgloblji izmed štirih znanih. Karbonatni rezervoar je omejen s tektonsko in erozijsko diskordanco med mezozojskimi in pliocenskimi kamninami. Trije mlajši rezervoarji polja Ika sestoje iz pleistocenskih peskov, meljastih peskov in meljevcev z laminami gline in laporja. Naloga raziskave je bila oceniti »verjetnost uspeha« (okr. POS Probability Of Success) odkritja novih plinskih teles v obrobju dveh polj, bodisi v mezozojskih kamninah, ali pa v pleistocenskih plasteh. Oceno so uspešnoopravili s programom Microsoft Excel POS table, prilagojenim za analizirana območja hrvaškega dela Padske udorine, t.j. severnega Jadrana. Metoda je zasnovana in prilagojena podobnim ocenjevanjem POS, ki so jih prvotno uporabljali za računanje geološke verjetnosti odkritij ogljikovodikov v hrvaškem delu sistema Panonskekadunje (okr. CPBS, Croatian part of the Pannonian Basin System).

Ključne besede: severni Jadran, verjetnost uspeha, mezozoik, pleistocen, geološko modeliranje 


\section{Introduction}

The Ivana and Ika Fields are located in the North Adriatic exploitation area, which is located about $50 \mathrm{~km}$ southwest of Pula. Ika Gas field was discovered in 1978 with 'Jadran -18/1' exploration well. From the end of the 1970's through the 1980's, fifteen wells were made in the area of Ika gas field. In 2004 and 2005, five production wells were made, and the last two wells were made during 2008 and 2009 [1]. Ivana gas field was discovered with the 'Jadran -6 ' well in 1973. Sixteen more wells were drilled, of which two were negative and one was written off because of different problems. There are five platforms on Ivana Gas field: Ivana -A (five wells, production started in 1999.), Ivana -B (two wells, production started in 2001), Ivana -C (one well, production started in 2006), Ivana -D (one well, production started in 2006) and Ivana -E (three wells, production started in 2000) [2]. Other gas fields near the south western coast of Istria were given names: Ida, Ana, Vesna, Irina and Annamaria, and these along with these the gas fields Ivana and Ika makeup the exploitation area in North Adriatic (Figure 1). The Izabela Field forms the Izabela exploitation area, and Marica and Katarina Fields together form the Marica exploitation area

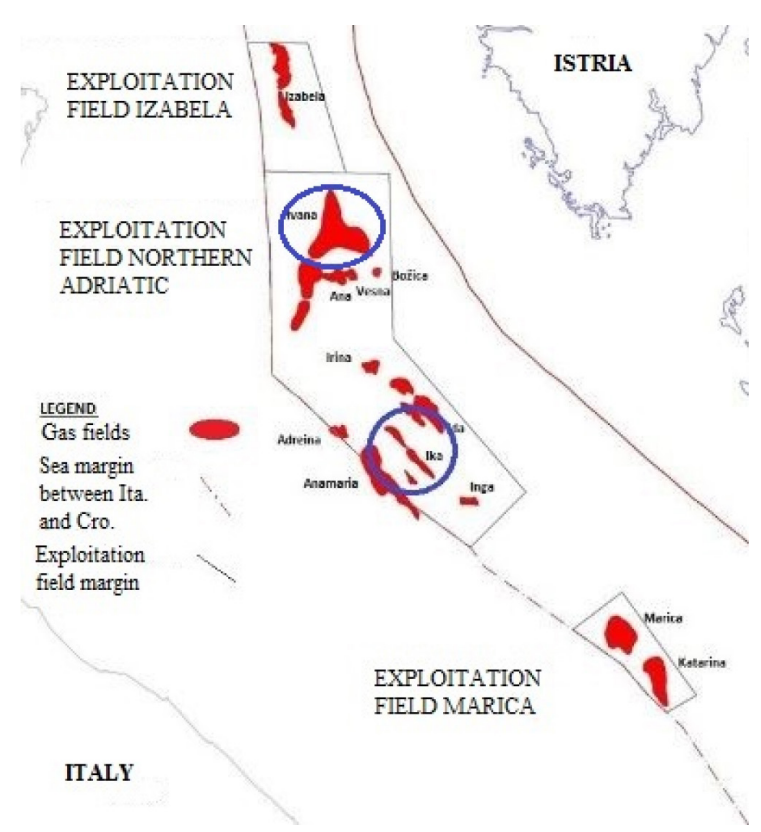

Figure 1: Exploitation fields in Croatian part of Northern Adriatic (Režić, 2016) [10]
(Figure 1). Ika, Ivana, Marica and Annamaria Fields are larger and more important, while Ida, Irina, Irma, Ksenija, Catherine, Isabelle and Koraljka Fields are smaller. The hydrocarbon explorations resulted in the discovery of gas reservoirs in the sediments of the Pleistocene. Gas is located in the loose sands that are few metres thick and have depth of 500 to $1000 \mathrm{~m}$ [3]. To calculate the geological probability or discovery risk (POS) for new hydrocarbon accumulations, the known deterministic process was used. This process can, with some changes and additions, be applied to different reservoir lithologies in any -oil-gas depression or basin [4]. The aim was to calculate the POS for new quantities of gas within Ivana and Ika Fields, that is in the parts of the Ivana (Ivana and Ika Fields) and Mali Alan (Ika Field) Formations [5], in Pleistocene deposits and Mesozoic carbonates.

\section{Basic geological settings in the Northern Adriatic}

The Adriatic Basin is divided into several depressions which were formed during the Miocene and Pliocene [3]. In Miocene, three depressions were formed: Dugi Otok, South Adriatic-Albanian and Molise. In Pliocene, depressions that opened are: Venetto, Po, Marche-Abruzzi, Middle Adriatic, Bradano and Adriatic - Ionian [3] (Figure 2). Dugi Otok Depression, the eastern parts of Po Depression, the eastern parts of Middle Adriatic Depression and a small part of the South-Albanian Depression are located in the Croatian part of Adriatic Sea [3]. The largest are Po and South Adriatic-Albanian Depressions, but none of these have stable margins and sedimentation conditions, which is expressed through the unequal compliance of sedimentation space and local discordant relations between depositional units, and consequently in the type and thicknesses of lithostratigraphy units. Most of the Po Depression is located on land between the Southern Alps and the Apennines, and its eastern part lays under the Adriatic Sea, reaching approximately $50 \mathrm{~km} \mathrm{W-SW}$ from the shore of Istria Peninsula, where the Croatian gas fields in the North Adriatic are located. The Po Depression is filled 


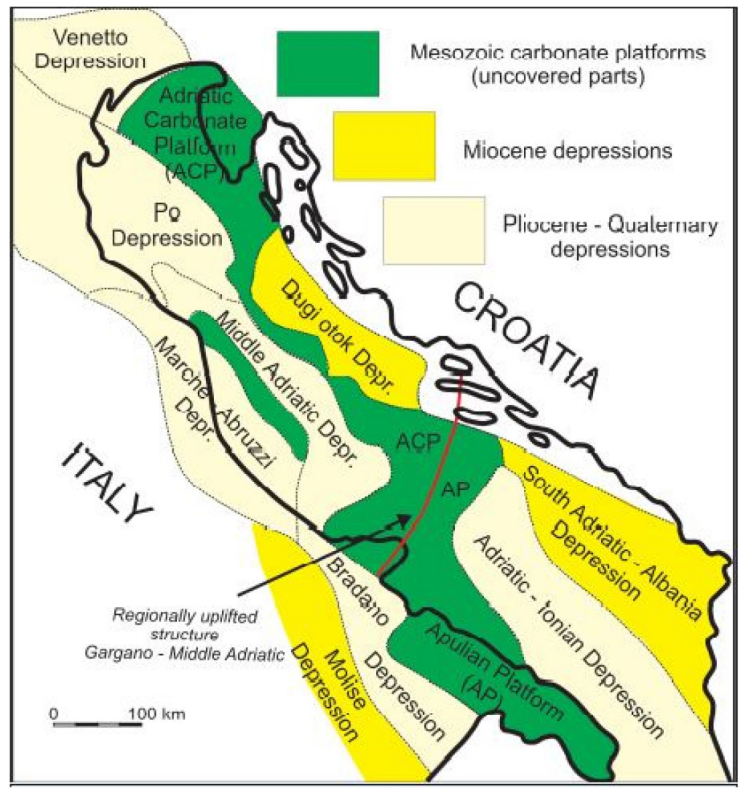

Figure 2: Depressions in Adriatic offshore (complied after Prelogović \& Kranjec, 1983; Velić \& Malvić, 2011) [11, 12]

with Pliocene - Pleistocene sediments and they are covered by Holocene sediments [3]. During the Pliocene, this area was completely covered with sea and spanned all the way to the edge of the Istrian Subplatform. Detritus is originally from the Alps and its total thickness may locally be higher than $6,000 \mathrm{~m}$ in the Italian section. In the Croatian part, prodelta lithofacies was dominant because of the distance from river Po palaeo mouth, which gradually spread to the SE. 'Turbidites were carrying the bulk of the material in the shallow, hemipelagic environment with depths up to 200 m' [6]. Alteration of turbidite and hemipelagic facies is the main characteristic of sedimentary sequences in the Croatian part of the Po Depression during the Pleistocene [6]. These lithofacies are described by different lithostratigraphic nomenclature in the Croatian and Italian part of the Po Depression $[5,6]$.

\section{Pliocene and Pleistocene depositional environments in the Northern Adriatic}

During the Pliocene, which covers the period from 5.332 million years ago (Ma) to $2.588 \mathrm{Ma}$, pelites were deposited in the Northern Adriatic. As sea level increased, the Adriatic Sea outlines became similar to the present outlines, but it the sea covered a greater area (Figure 3)

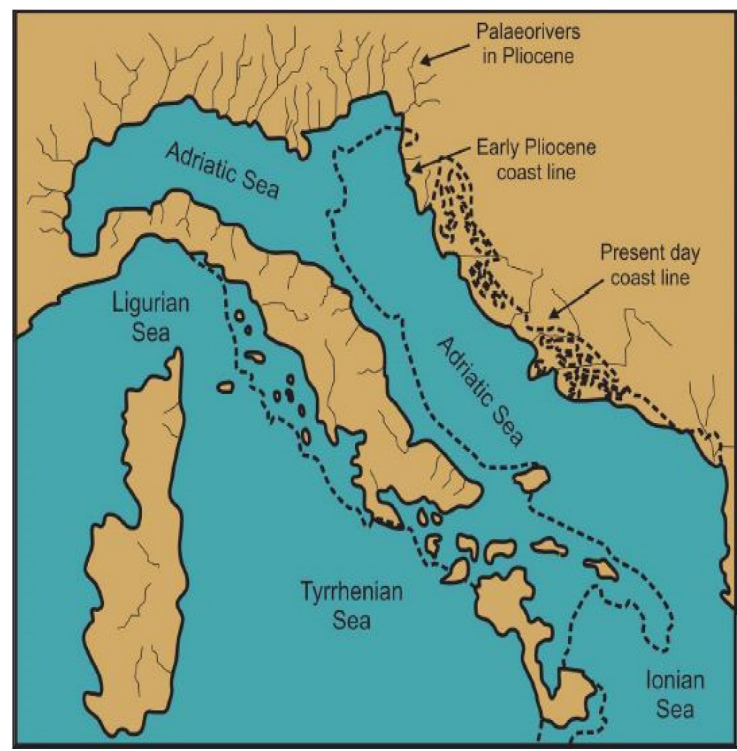

Figure 3: Adriatic sea borders in Lower Pliocene (Velić \& Malvić, 2011) [11]

[5]. Planktonic and benthic foraminiferas in the Early Pliocene indicate warm climate and precipitation in an open sea environment. Because of moderate to cold climates during the glacial period named as Biber $(\approx 2.5 \mathrm{Ma}$ ), Late Pliocene is marked by less diverse and smaller number of planktonic foraminiferas [5]. The thickness of Pliocene deposits is higher in the Italian part of Po Depression because of the proximity of the Po River which brought detritus from the Alps, and also because of subsidence of areas of the Northern Adriatic that occurred in the Late Pliocene [5]. Pleistocene lithofacies are significantly different from the Pliocene and they are marked with alteration of sands and silts. As the Po delta moved to the SE, the sand and silt reached the Croatian part of depression. Total thickness of Pleistocene sediments in the Croatian part is between 900 and $1500 \mathrm{~m}$, within which individual sand reservoirs can be thicker than $20 \mathrm{~m} \mathrm{[6].} \mathrm{In} \mathrm{the} \mathrm{present} \mathrm{borders,} \mathrm{the} \mathrm{Adri-}$ atic Sea had formed after the last glaciation Würm $(0.015 \mathrm{Ma})$, in which today's great area of Adriatic seabed was exposed as continental environment for the last time during the Quaternary (Figure 4) [5]. 


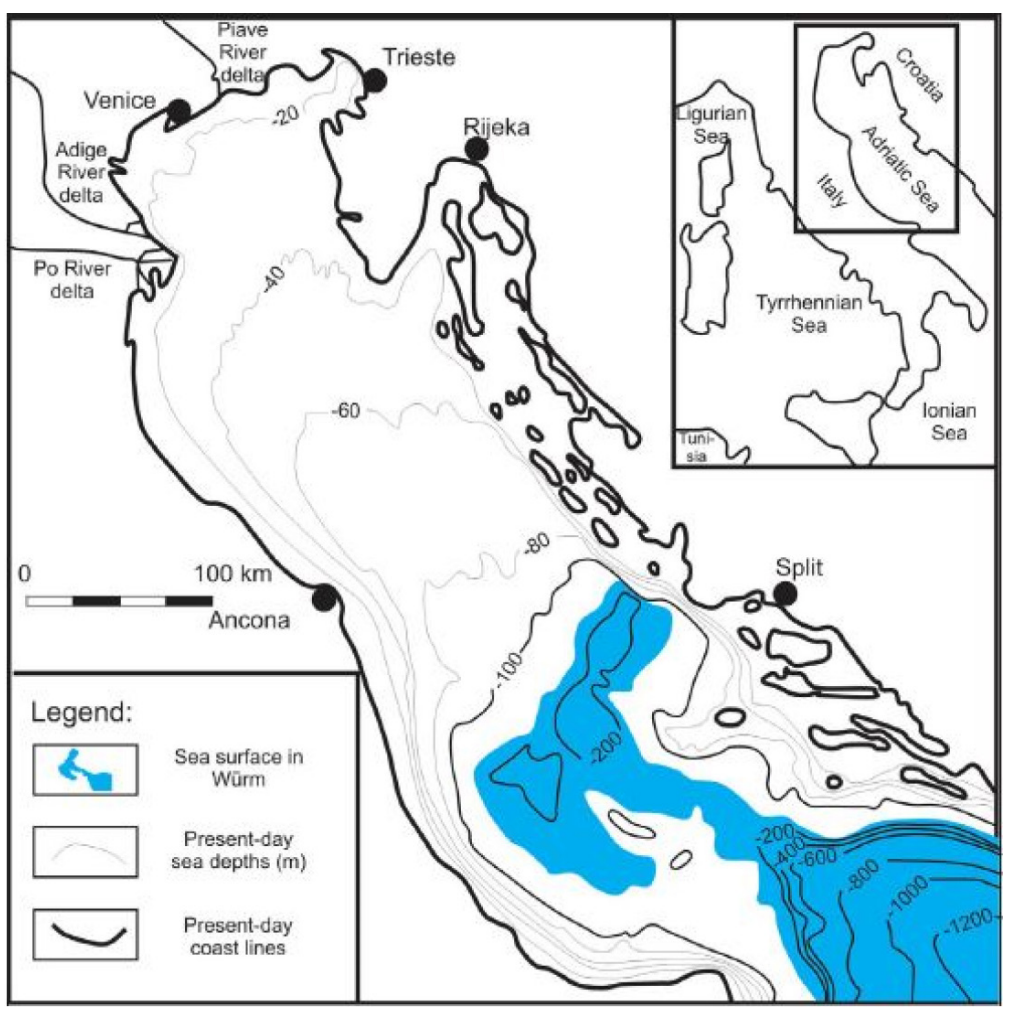

Figure 4: Borders of Adriatic sea during Wurm (complied after Velić \& Malvić, 2011; Correggiari et al., 1996) [11, 13]

\section{The role of lithostratigraphy in the Northern Adriatic hydrocarbon exploration (Mali Alan, Istria and Ivana Formations)}

The reservoir in the Ika Field is unique in the Croatian part, because it is the only reservoir with fractured carbonates. The carbonate 'buried hill' in the structure is laid shallower than the regionally suck rocks are mapped. These fractured Mesozoic limestones belong to the Mali Alan Formation. Lithotypes have wide variations regionally, with pores created because of dissolution. Dolomized limestone and dolomite are also observed [7]. The Istria Formation is shallower that encompasses the clastic sediments deposited during the Pliocene. The prevailing lithology of this formation consists of marls and clays. Silty clay lenses were found, but larger fractions like sand weren't found. This formation is trangressive and deposited over erosional unconformity. The thickness of the Istria Formation varies within the Po Depression, but it is much thicker in the Italian part because of the proximity of palaeo Po River and the detritus source. The microfossil content of the formation is dominated by planktonic foraminiferas. The formation is very homogeneous and is not divided into members [6].

During the Early Pleistocene turbidities emerged in the Croatian part as well and deposited inside the Ivana Formation, which is mostly transgressive with local unconformities in some places [5]. The formation involves alteration of clays and silty sands in which locally are proven gas reservoirs. The thickness is about $400-900 \mathrm{~m}$, which depends on the paleo surface and the depositional history during Pleistocene and Holocene [5]. Both clastic formations could be the sources of organic matter from which biogenic (bacterial) gas is locally created, but larger volumes are probably created and preserved into the Ivana Formation. However, geographically, it is still impossible to quantify the biogenic gas production, but it is only assumed based on the structural position as expected migration paths and the percentage of terrestrial components in the totally deposited material. Such assumptions could lead to the following statements: 
- In the Croatian part, gas is generated mostly within the Ivana Formation, in horizons with a high content of terrestrial organic matter, and trapped with the overlying impermeable lithofacies;

- In the Italian part, generating horizons with biogenic gas are developed largely in the equivalents of both formations, Istria and Ivana.

- A larger amount of biogenic gas is crated in Italian part of the Po Depression due to much thicker deposits and therefore, the quantity of organic matter is larger. Also, in the Italian part, the proximity of the source of organic matter is closer, and therefore there is less mechanical weathering;

- The migration pathways can vary between 'in situ' (primary migration), 'local' (few kilometres) to 'regional' (tens kilometres). Here, it is assumed that most of the gas in the Croatian part of the Po Depression had been accumulated from the secondary migration that started in the Italian part $(10-30 \mathrm{~km}$ of migration pathways), due to the total thickness of pelitic and organic rich deposits.

\section{Calculation of geological probability for new gas discoveries in the Ika and Ivana Fields}

In Croatia, for the calculation of geological risk or probability (POS), a well known deterministic process had already been used for hydrocarbon discovery in existing or new plays and prospects in the Drava Depression [8]. Such procedure of calculating the geological risk can, with modifications, be applied to almost all reservoirs in any oil and gas basin or depression. But it is necessary to geographically and geologically define the area in which such calculation is made [4] to define the geological event and probabilities.

Mathematically, geological probability is the simple deterministic product of probabilities related to several geological categories, as apparent independent probability events, and the final result is the assessment of new hydrocarbon discoveries. Such an assessment may be more or less subjective and depends primarily on whether each individual category was esti- mated from an expert knowledge (engineer), or taken from official probability tables. Furthermore, although the initial setting is that these are independent events, they are often intertwined and condition each other. However, such a connection is far too complex to be reliable and independently described, even with geomathematical methods, therefore, this procedure (POS) is today one of the ways of such an assessment. Consequently, a similar assessment can be oriented more stochastically (instead of deterministically), especially those pertaining to the reservoir variables, but such an approach should match the behaviour of natural phenomena (or geological processes) that are commonly found between determinism and chaos, namely, the area of stochastic [4].

\section{Short theory of geological risk (probability)}

The calculation is largely a subjective process, because every single category can be estimated by the expert (geologist), from officially accepted probability tables or with additional checks of probability (called as benchmarking), following the new well data. In general, the interesting stratigraphic intervals, considering hydrocarbon reservoirs, are analyzed deterministically by estimating five basic independent categories: (1) trap, (2) reservoir, (3) migration, (4) source rock, and (5) preservation of hydrocarbons.

Events that are typical within the category are obtained on the basis of well data, well logging, seismic data, core analysis, laboratory analyses and geological interpretations. Based on these data sets, it is easy to choose the event probability within the variables in the table of probabilities. It is followed by the product of the values of event and the estimation of a geological probability (POS). The values of the variables (events) in POS tables are chosen from discrete values (deterministically) as probability $0-1$. The lithological sequence of Ika and Ivana Fields can be divided into two stratigraphic intervals:

- Pleistocene loose sands (Ivana and Ika Fields);

- Mesozoic carbonates of (Ika Field).

Geological probability (POS) is calculated for each observed stratigraphic interval using the following equation (1) [4]: 
$P O S=p(t) \times p(r) \times p(m) \times p(s r) \times p(h c p)$

POS - geological probability;

$P(t)$ - value considering trap category;

$P(r)$ - value considering reservoir category;

$P(m)$ - value considering migration category;

$P(s r)$ - value considering source rock category;

$P(h c p)$ - value considering preservation of hydrocarbons.

\section{Calculation of geological risk using the program 'GEOPROBE Modelling 1.1' adapted for the Po Depression}

As already mentioned, MS Excel was used to calculate the probability of the observed geological events that are adapted for Ika and Ivana gas fields. Such events were adapted to the study area. The calculation of geological probability varies depending on whether it is done in sand or carbonates. In the beginning, the stand-alone application GEOPROBE Modelling (GPM) 1.1 [9] was used to calculate the POS on the Ika and Ivana Fields, based on the POS table valid in the CPBS. However, the basics of GPM 1.1 were also applied also in the Northern Adriatic, where each category was described with certain geological events, wherein each event joined the probability in the interval from 0.05 (highly uncertain to exist at all) to 1.0 (proven).

Geological events used in GPM 1.1 were divided into five groups according to probability: $p=1$ for certain, $p=0.75$ for very probable, $p=0.5$ for probable, $p=0.25$ for low probable and $p=0.05$ for not proven / improbable events. The category 'Trap' was divided into the sub-categories 'Structural', 'Stratigraphic or combined' and 'Quality of cap rock'. The category 'Reservoir' was described with the subcategories 'Reservoir type' and 'Porosity features'. The category 'Source rock' was divided into subcategories 'Source facies', 'Maturity' and 'Data source'. The category 'Migration' contained sub-categories 'Hydrocarbon (HC) shows', 'Trap position' and 'Timing. The category 'HC preservation' was described with subcategories: 'Reservoir pressure' and 'Formation water'. Each subcategory was further divided into events with accompanied probabilities. However, the main property of this application was the exclusive applicability into clastic environments of the CPBS.

If such a probability table is applied to the Northern Adriatic clastic and carbonate environments, without modifications and just as a first test, the results are as follows. A probability value of the 'Trap' is 1 , because there are structural traps with proven cap rocks. Within the category of 'Reservoir', the best match would be with 'The Dolomites with secondary porosity' and 'Secondary porosity 1-5\%', that is probability $0.75(p=0.75)$. Subcategory events used for the category 'Source rock' are: 'Source facies' ('Kerogen Type III'), 'Maturity' ('Sediments are in metagenesis phase') and 'Data Source' (Geochemical analysis of the cores and fluids), and the probability of the category 'Source rock' is 0.5265 . The category 'Migration' is described with events in subcategories: 'HC shows' ('Production of hydrocarbons'), 'Position of the trap' (Long migration path $>10 \mathrm{~km}$ ) and Timing (the trap younger than source rock). The probability category 'Migration' is obtained by multiplying the probability of independent events and it has a value of 0.1875 . The category 'Preservation of hydrocarbons' with subcategories and events 'Reservoir pressure' ('Greater than hydrostatic') and 'Formation water' ('Still aquifer') gives the probability of $1(\mathrm{p}=1)$. The calculation ends when probabilities of five categories are multiplied, which is given in Expression 2:

$$
\begin{aligned}
& P O S=p(t) \times p(r) \times p(m) \times p(s r) \times p(h c p) \\
& =1 \times 0.75 \times 0.5625 \times 0.1875 \times 1=0.0791 \\
& =7.91 \%
\end{aligned}
$$

where:

$p(t)$ - 'Trap' probability;

$p(r)$ - 'Reservoir' probability;

$p(m)$ - 'Migration' probability;

$p(s r)$ - 'Source rock' probability;

$p(h c p)$ - 'HC preservation' probability.

According to the chosen carbonate reservoir rocks in this model, the geological probability to find additional gas discoveries in such rocks in the wider zones of Ika and Ivana Fields is 7.91\%. However, such approach has obvious disadvantage because some geological events correspond exclusively to the clastic environments in CPBS's, which does not correspond to 
the depositional history of the Northern Adriatic, especially for carbonate deposits. Thus, the original methodology has to be adapted to the geological conditions of the Northern Adriatic, which is described in the following subsections.

\section{Application of adapted POS for new possible carbonate reservoirs in wider zone of Ika Field}

In the next subchapters, the table valid for GPM 1.1 is completely reviewed and adapted for the analysed geological environments in the Northern Adriatic, particularly for the lithologies in the Mali Alan and Ivana Formations. The values of the probability for events range from 0 to 1 and are made deterministically. Their value estimation is based on the frequency of occurrence of a certain type of traps, reservoirs, source rocks and migrations in the area of the Croatian part of the Po Depression. To calculate the geological probability of new gas occurrence in carbonates (proven in the Ika Field) in the category of 'Trap' used events in the subcategory 'Structure' are: 'Anticline' or 'buried hill', 'Faulted anticline or fractured rock' and Undefined structural trap'. Within the subcategory, the 'Stratigraphic or combined' events are: 'the rocks beneath unconformities', as gas reservoir in carbonates is below the unconformity and 'Undefined stratigraphic trap' for the undrilled areas. In the subcategory 'Quality of cap rock', the probability division $1,0.66$ and 0.33 were used for the first time to cover the three proven events - clayey silts and clays with a smaller portion of sand and silt, clayey silts and clays with a higher portion of sand and silt, and impermeable rock. The category 'Reservoir' is described with subcategories: 'Reservoir type' and 'Porosity'. The subcategory 'Reservoir type' is made of the events that describe what type of carbonates could be there in the Ika Field. The subcategory 'Porosity' is described with the events depending on whether it is primary or secondary porosity in rocks that are being examined. The category 'Source rock' is described with subcategories 'Source facies' with the event 'the deposition of predominantly terrestrial organic matter, subsequently decomposed by bacteria', which is adapted because of the already described migration of gas in the area of the Croatian from the Italian part of the Po Depression. In the subcategory 'Data sources', the events are selected depending on whether the data is obtained by geochemical analyses or thermal modelling. The category 'Migration' contains sub-categories 'HC shows', 'Position of trap' and 'Timing'. The subcategory 'HC shows' is described with two events, depending on whether or not there are any hydrocarbons. The subcategory 'Position of trap' simulates the events that show whether the reservoir rock is positioned in close or distant migration. The subcategory 'Timing' is described with the events 'The trap is younger than matured source rocks' and 'the trap is older than mature source rocks'. The category 'HC preservation' is described with the subcategory 'Reservoir pressure' and subcategory 'Formation water' that is then described with the events of 'Active aquifer' and 'Still aquifer'. The 'Reservoir pressure' events are selected depending on whether a pressure in reservoir is higher, equal or lesser than the hydrostatic pressure.

The probability values are mostly associated with the case of three options, where $p=1$ for the certain event, $p=0.66$ for reliable and $p$ $=0.33$ for unreliable event, or for a case with two options, where $\mathrm{p}=1$ for reliable and $\mathrm{p}=$ 0.5 for medium reliable (probable) events. In some cases (like porosity), the number of events asked for four probabilities $(1,0.75,0.5$ and 0.25 , as seen in GPM 1.1). And in all the cases, the probabilities are closed with 'unproven' event and value 0.05 . Such POS table is transferred in Excel (Tables 1 and 2), and the final result differs depending on whether the probability is calculated in sands or carbonates. The calculation equation is similar to that in GPM 1.1 , that is, it is the multiplication of independent probabilities for categories or subcategories.

The main geological settings in the Northern Adriatic could be expressed with following categories, subcategories and events. Traps are mostly faulted anticlines, cracked rocks, sand lenses and mild anticlines. The subcategory describing the cap rocks has also changed, because in Northern Adriatic, the overlying rock section consists of recent sediments and sand with an increased proportion of silt or clay, which is laterally extended. The category 
Table 1: Categories, subcategories and events in Excel table, used as a model for calculation of geological risk in carbonates in Northern Adriatic (translated from Režić, 2016) [10]

\begin{tabular}{|c|c|c|c|c|c|c|c|c|c|}
\hline TRAP & p & RESERVOIR & p & SOURCEROCKS & $p$ & MIGRATION & $\mathrm{p}$ & HC PRESERVATION & $p$ \\
\hline Settrap & & Reservoittroe & & Source facies & & Ho showe & & Peserveinnessure & \\
\hline Structural & 1 & Fissured and/or dissolved carbonates & 10 & Deposition of predominantly terrestrial organic matter subbecuently constructed by bacteria & 1 & HC rooduction & 1 & Higher than hydrostatic & 1 \\
\hline \multirow[t]{2}{*}{ Stratigraphicor combined } & 1 & Compacted carbonte rocks & 0,66 & & & HCare not observed & 0,05 & Approximately hydrostatic & 0,66 \\
\hline & & Biohermes or biostromes & 0,33 & Data sources & & & & Lower than hydrostatic & 0,33 \\
\hline Structural & & Undefined reservoir rock & 0,05 & Geochemicel analysis on cores and fluids & 1 & Position of trap & & Undefined reservoir pressure & 0,05 \\
\hline Anticine or burried hill & 1 & & & Geochemical analysis in analogy with analysis in other locations & 0,75 & Trap is located i n proven migration distance & 1 & & \\
\hline Faulted antidine or fragmented rock & 1 & Porosity features & & Thermal modeling and calculation & 0,5 & Short migration pathway $<=10 \mathrm{~km}$ & 0,66 & Formation water & \\
\hline \multirow[t]{2}{*}{ Undefined structural framework } & 0,05 & Primary porosity $10 \%$ & 1 & Thermal modeling at few locations & 0,25 & Long migration pathway $>10 \mathrm{~km}$ & 0,33 & Still aquifer & 1 \\
\hline & & Secondary porosity $25 \%$ & 1 & Undefined data sources & 0,05 & Undefined migration distance & 0,05 & Active aquifer & 0,5 \\
\hline Stratigraphic or combined & & Primary porosity $5 \%-10 \%$ & 0,75 & & & & & & \\
\hline Rocks under discordance & 1 & Secondary porosity $1 \% .5 \%$ & 0,75 & & & Timing & & & \\
\hline \multirow[t]{3}{*}{ Undefined stratigraphic framework } & 0,05 & Primary porosity $<5 \%$ & 0,5 & & & Trap is younger than matured source rocks & 1 & & \\
\hline & & Secondary porositiy < $1 \%$ & 0,5 & & & Trap is older than matured source rocks & 0,05 & & \\
\hline & & Permeability $<\times 10^{* *}(-3) \mu m^{* *}(2)$ & 0,25 & & & & & & \\
\hline Quality of cap rock & & Undefined porosity values & 0,05 & & & & & & \\
\hline Permeable rocks with localy lower silt/clay content & 1 & & & & & & & & \\
\hline Permeable rocks with localy higher sitt/clay content & 0,66 & & & & & & & & \\
\hline Impermeable rocks & 0,33 & & & & & & & & \\
\hline Undefined cap rock & 0,05 & & & & & & & & \\
\hline
\end{tabular}

'Reservoir' is described with the same events as GPM 1.1, but there have been changes in the types of reservoir rocks and porosity, which has reduced. In the description of the category 'Source rock' there is no subcategory 'Maturity' with events ('Late diagenesis', 'Early catagenesis', 'Catagenesis phase' and 'Metagenesis phase'). Instead a new geological event is added, 'Deposition of predominantly terrestrial organic matter subsequently decomposed by bacteria', in order to take into account the large amounts of terrestrial organic matter that is deposited and biologically altered in the Po Depression. The category 'Migration' remained approximately the same with the same subcategories as GPM 1.1. Events in subcategories within the category 'Migration' are modified as follows: subcategory 'HC shows' is described with events 'HC production' and 'HC are not observed'. Subcategory 'Position of trap' is described with the events: 'the trap is located in a proven migration distance', 'short migration path <= $10 \mathrm{~km}$ ', 'long migration path $>10 \mathrm{~km}$ ' and 'Undefined migration distance'. The category 'HC preservation' is described with subcategories 'Reservoir pressure' and 'Formation water', with associated probability events.

When all new events had been applied, the result came from the following selections: multiplying the probability of events 'anticline or buried hill" and 'clayey silts with low portion of silt or clay' in the category 'Trap', the probability result of that category is 1 . In the category 'Reservoir', the events 'Fissured and / or dissolved carbonates' and 'Secondary porosity $1-5 \%$ ' gives the probability of 0.75 for the category 'Reservoir'. Within the category 'Source rocks' with associated subcategories and events, 'the deposition of predominantly organic matter subsequently modified the action of bacteria' and 'the geochemical analysis of the cores'. Multiplying these two events, the probability for 'Source rock' category is $p=1$. The category 'Migration' with events 'production of hydrocarbons', 'long migration path $>10 \mathrm{~km}$ ' and 'the trap is younger than matured source rocks' has the probability $\mathrm{p}=0.33$. Within the category 'Reservoir pressure', it is important to choose whether the reservoir pressure is higher, equal or lesser than the hydrostatic. The probability of this category is 1 . The probability calculation for new gas deposits in carbonates is shown with Equation 3.

$$
\begin{aligned}
& P O S=p(t) \times p(r) \times p(m) \times p(s r) \times p(h c p) \\
& =1 \times 0.75 \times 1 \times 0.33 \times 1=0.2475=24.75 \%
\end{aligned}
$$

where:

$\mathrm{p}(\mathrm{t})$ - 'Trap' probability;

$\mathrm{p}(\mathrm{r})$ - 'Reservoir' probability;

$\mathrm{p}(\mathrm{m})$ - 'Migration' probability;

$\mathrm{p}(\mathrm{sr})$ - 'Source rock' probability;

p(hcp) - 'HC preservation' probability.

The geological probability for new gas reservoirs in carbonates of Ika gas field is $24.75 \%$, according to the probability values of categories, subcategories and events as shown in Table 1. 
Table 2: Categories, subcategories and events in Excel table, used as a model for calculation of geological risk in loose sands in Northern Adriatic (translated from Režić, 2016) [10]

\begin{tabular}{|c|c|c|c|c|c|c|c|c|c|}
\hline TRAP & $p$ & RESERVOIR & $p$ & SOURCE ROCKS & $p$ & MIGRATION & $\mathrm{p}$ & HCPRESERVATION & $p$ \\
\hline & & & & & & & & & \\
\hline Set trap & & Reservoir type & & Source facies & & HC Shows & & Reservoir pressure & \\
\hline Structural & 1 & Sands with lower portion of silt/day & 10 & Deposition of predominantly terrestrial organic matter subsequently constructed by bacteria & 1 & HCproduction & 1 & Higher than hydrostatic & 1 \\
\hline \multirow{2}{*}{ Stratigraphic or combined } & 1 & Sands with higher portion of silt/clay & 0,5 & & & HCare not observed & 0,05 & Approximately hydrostatic & 0,66 \\
\hline & & Undefined reservoir rock & 0,05 & Data sources & & & & Lower than hydrostatic & 0,33 \\
\hline Structural & & & & Geochemical analysis on cores and fluids & 1 & Position of trap & & Undefined reservoir pressure & 0,05 \\
\hline Antidine or burried hill & 1 & Porosity features & & Geochemical analysis in analogy with analysis in other locations & 0,75 & Trap is located in proven migration distance & 1 & & \\
\hline Faulted anticline & 1 & Primary porosity $25 \%$ & 1 & Thermal modeling and calculation & 0,5 & Short migration pathway $<=10 \mathrm{~km}$ & 0,66 & Formation water & \\
\hline \multirow{2}{*}{ Undefined structural framework } & 0.05 & Secondary porosity $>10 \%$ & 1 & Thermal modeling at few locations & 0,25 & Long migration pathway $>10 \mathrm{~km}$ & 0,33 & Still aquifer & 1 \\
\hline & & Primary porosity $10 \% \cdot 25 \%$ & 0,75 & Undefined data sources & 0,05 & Undefined migration distance & 0,05 & Active aquifer & 0,5 \\
\hline Stratigraphic or combined & & Secondary porosity $5 \% \cdot 10 \%$ & 0,75 & & & & & & \\
\hline Sand lenses surrounded with impermeable rocks & 1 & Primary porosity < 10\% & 0,5 & & & Timing & & & \\
\hline Pinched out trap in the direction of lift & 0,66 & Secondary porositiy $<5 \%$ & 0,5 & & & Trap is younger than matured source rocks & 1 & & \\
\hline Trap closed with discordance & 0,33 & Permeability $<1 \times 10^{* *}(-3) \mid \mathrm{m}^{* *}(2)$ & 0,25 & & & Trap is older than matured source rocks & 0,05 & & \\
\hline Pinched out sands or faulted trap & 0,05 & Undefined porosityvalues & 0,05 & & & & & & \\
\hline \multirow[t]{2}{*}{ Undefined stratigraphictrap } & & & & & & & & & \\
\hline & & & & & & & & & \\
\hline \multicolumn{10}{|l|}{ Quality of cap rock } \\
\hline Recentsediments & 1 & & & & & & & & \\
\hline Clayey marls & 0,5 & & & & & & & & \\
\hline Undefined cap rock & 0.05 & & & & & & & & \\
\hline
\end{tabular}

\section{Application of adapted POS for new possible sand reservoirs in the Ika and Ivana Fields}

POS for silty and pure sands is similar to excel table for carbonates, but only adapted for such type of reservoirs (Table 2).To calculate the geological probability for sand reservoirs, same categories with subcategories and corresponding events as in Table 1 for carbonates are used. Within the category of 'Trap', the events are 'anticline or brachy anticline' and the event 'Recent sediments' in the subcategory 'The quality of cap rock'. The resulting probability for category 'Trap' is $p=1$. In the category 'Reservoir', the events are 'Sands with lesser portion of clay or silt' and the 'Primary porosity $>25 \%$ ' within the subcategory 'Porosity'. The value obtained for probability is 1 . Other categories with appropriate events and their probabilities are the same as in table for carbonates, and the calculation of the geological probability is given Expression 4:

$$
\begin{aligned}
P O S= & p(t) \times p(r) \times p(m) \times p(s r) \times p(h c p)= \\
& 1 \times 1 \times 1 \times 0.33 \times 1=0.33=33 \%
\end{aligned}
$$

where:

$\mathrm{p}(\mathrm{t})$ - 'Trap' probability;

$\mathrm{p}(\mathrm{r})$ - 'Reservoir' probability;

$\mathrm{p}(\mathrm{m})$ - 'Migration' probability;

$\mathrm{p}(\mathrm{sr})$ - 'Source rock' probability;

p(hcp) - 'HC preservation' probability.

The geological probability for new gas reservoirs in the sands of Ika and Ivana Fields is $33 \%$. The probability values with categories, subcategories and events are given in Table 2.

\section{Discussion and Conclusion}

The main problem for the present calculations was the undefined source rocks volumes in the Croatian part of the Po Depression. On the contrary, these facts are well known in the Pannonian Basin System. Here, it was assumed that minor gas volumes in the Croatian part were generated in situ, and the rest migrated from the Italian part of the Po Depression (migration paths from about 10 to $30 \mathrm{~km}$ ). The base for such assumption were the total thicknesses of Pliocene and Pleistocene clastic sequences in both parts, and the proximity of the palaeo Po delta and prodelta. Therefore, the category 'Source rock' had been reduced to a sub-category 'Source facies' and 'Data Source' with associated events.

Further, important modifications were related with the subcategory 'Structural' within the category 'Trap' that is adapted to Northern Adriatic geological settings. Within the subcategory 'Porosity', the values were changed for carbonates because they were compact and mostly less permeable rocks than sandstones. However, where sands were analyzed, the values in subcategory 'Porosity' in the Ika and Ivana Fields were increased in comparison to the CPBS, as the proven values of porosity were about $30 \%$ in sand reservoirs. Within the category 'Migration', the most important thing was to point out that compared to GPM 1.1, the modified event 'Trap is younger than the source rocks' has the probability $\mathrm{p}=1$. Otherwise, if the trap is older 
than source rocks, there would be no gas accumulation, because there wasn't any significant uplifting, and consequently structural trapping. Eventually, the results showed that for the wider area of Ika Field, the probability of finding a new gas in carbonates is 0.2475 , or $24.75 \%$, and in the sandy deposits in Ika and Ivana Fields 0.33 or $33 \%$. It was significantly higher than the probability obtained for the Northern Adriatic carbonates using unmodified GPM 1.1 of 0.791 or $7.91 \%$.

It can be concluded that in the wider area of Ika and Ivana Fields, in loose sands (Ivana Formation) and carbonates (Mali Alan Formation, Ika Field), probabilities of $24.75 \%$ and $33 \%$ are large enough to continue the research and drilling with a positive outcome. Generally, when there is hydrocarbon exploration anywhere in the world, these results are considered to be of very high value. And each company, even a small one, will take the risk, because there would be a discovery in at least one of the three wells. The presented results are enough to further justify the exploration and drilling in the Northern Adriatic. Any company needs to make a decision and take the risk of $60-70 \%$ for 'dry wells', which is also normal in oil and gas exploration. All the levels of management should stand behind these decisions, and assume their responsibility.

\section{References}

[1] Đureković, M., Jovović, S., Krpan, M., Jelić - Balta, J. (2002): Ika gas field characterization and modelling, Nafta, 53, 8, 273-282.

[2] Živković, V. (2015):Production platforms of exploitation field North Adriatic (Proizvodne platforme eksploatacijskog polja Sjeverni Jadran), DiplomaThesis, University of Zagreb, Faculty of Mining, Geology and Petroleum Engineering, Zagreb, 46 p. (in Croatian, with the English summary

[3] Velić, J. (2007): Geologijaležištanafteiplina (Geology of oil and gas reservoirs). University of Zagreb, Faculty of Mining, Geology and Petroleum Engineering, Zagreb; 342 p. (in Croatian)

[4] Malvić, T. (2009): Stochastical approach in deterministic calculation of geological risk - theory and example (Stohastički pristup u determinističkom izračunu geološkoga rizika - teorija i primjer). Nafta, 60, 12, 651-662.

[5] Malvić, T., Velić, J., Cvetković, M., Vekić, M., Šapina, M. (2015): Određivanje novih pliocenskih, pleistocenskih i holocenskih litostratigrafskih jedinica u hrvatskom dijelu Jadrana (priobalju) [Definition of new Pliocene, Pleistocene and Holocene lithostratigraphic units in the Croatian part of the Adriatic Sea (shallow offshore)], Geoadria, 20, 2, 85 - 108. (in Croatian)

[6] Malvić, T., Đureković, M., Šikonja, Ž., Čogelja, Z., Ilijaš, T., Kruljac, I. (2011): Istraživačke i proizvodne aktivnosti u Sjevernom Jadranu (Hrvatska) kao primjer uspješnog zajedničkog ulaganja Ine (Hrvatska) i ENIja (Italija) [Exploration and production activities in northern Adriatic Sea (Croatia), successful joint venture INA (Croatia) and ENI (Italy)],Nafta, 62, 9-10, 293-296. (in Croatian and English)

[7] Pavić, N. (2007): Petrofizikalne značajke ležišnih stijena plinskih polja u Sjevernom Jadranu (Petrophysical characteristics of reservoirs rocks in Gas fields of Northern Adriatic),Diploma Thesis, University of Zagreb: Faculty of Mining, Geology and Petroleum Engineering, Zagreb, 41 p. (in Croatian)

[8] Malvić, T. (2003): Naftnogeološki odnosi i vjerojatnost pronalaska novih zaliha ugljikovodika u bjelovarskoj uleknini [Oil-Geological Relations and Probability of Discovering New Hydrocarbon Reserves in the Bjelovar Sag]. PhD thesis, University of Zagreb, Faculty of Mining, Geology and Petroleum Engineering, Zagreb, 123 p. (in Croatian and English)

[9] Malvić, T., Đureković, M., Rusan, I. (2006): Vjerojatnosni razredi i geološki događaji u izračunu geološke vjerojatnosti. 4th international petroleum congress »New Approaches and Methods in Evaluating Hydrocarbon Reserves«. Programme Committee (ed.). HAZU, RGNF, INA, Zagreb 16.-18. 11., Zagreb, 25-26.

[10] Režić, M. (2016): Opći model zaizračungeološkevjerojatnostinovihotkrićaplinanapodručjuSjevernogJadranauzprimjerplinskogpoljaIka (General model for the calculation of geological probability associated with new gas discoveries in the Northern Adriatic with an example of the Ika gas field), Diploma Thesis, University of Zagreb, Faculty of Mining, Geology and Petroleum Engineering, Zagreb, 48 p. (in Croatian with English summary)

[11] Velić, J., Malvić, T. (2011): Depositional conditions during Pliocene and Pleistocene in Northern Adriatic and possible lithostratigraphic division of these rocks (Taložniuvjetitijekompliocenaipleistocena u SjevernomJadranutemogućalitostratigrafskaraščlambanastalihstijena). Nafta, 62, 1-2, 25-32. 
[12] Prelogović, E., Kranjec, V. (1983): Geološki razvitak područja Jadranskog mora [Geological evolution of the Adriatic Sea]. Pomorski zbornik, 21, 387-405. (in Croatian)

[13] Correggiari, A., Roveri, M. and Trincardi, F. (1996) Late Pleistocene and Holocene Evolution of the North Adriatic Sea, Quaternario, 9, 2, 697-704. 
